\title{
Premature Burial and the Undertakers
}

\author{
Brian Parsons
}

Although legislation to register deaths was introduced in England and Wales in the 1830s, it was not mandatory for a physician to examine a body after death. For many people, the absence of a final check for signs of life led to fears of premature burial. In the 1890s, a pressure group called the London Association for the Prevention of Premature Burial (LAPPB) was founded to highlight the issue and it campaigned for improvements in death certification along with the building of "waiting" mortuaries. Despite this move, the lack of any large-scale evidence that people were being buried alive meant that there was little interest in achieving greater changes in law or practice. Furthermore, by this stage, the context of the disposal of dead bodies was changing, a development evident in the increased responsibility undertakers were given for the treatment of the corpse. This might have been an opportunity for undertakers to promote themselves as verifiers of mortality, offering the bereaved peace of mind by testing for death. However, the tentative moves to provide this service failed to gain any legitimacy because undertakers were seen as usurping the role of medical professionals, traditionally regarded as the chief certifiers of death.

B. Parsons $(\square)$

London, UK

e-mail: bparsonsfstl@gmail.com

(C) The Author(s) 2017

69

S. McCorristine (ed.), Interdisciplinary Perspectives on Mortality

and its Timings, Palgrave Historical Studies in the Criminal Corpse

and its Afterlife, DOI 10.1057/978-1-137-58328-4_5 
Historical in its approach, this chapter explores the landscape of the disposal of the dead in Britain from the 1830s, focusing, in particular, on the tension caused by the absence of secure certification of the dead and the changing role of the undertaker.

Concerns about premature burial, or "vivisepulchure" as Behlmer terms it, have existed in Britain since the eighteenth century, if not longer. ${ }^{1}$ This fear inspired many writers to speculate on the horrors of waking up in a coffin after interment: Edgar Allen Poe's "The Premature Burial" (1844) is one of most widely known takes on the subject. The possibility that a trance-like state could be mistaken for death stimulated people to invent "safety" coffins, many kitted out with warning devices that could be activated by the supposedly deceased. ${ }^{2}$ These fears carried through into the twentieth century, with the London coffin manufacturer Dottridge Bros continuing to market their "Life-Saving coffin" until around $1914 .^{3}$

Those with the greatest fear of being buried alive used their will to stipulate the means by which physicians should check for signs of life. For instance, Jeanette Caroline Pickersgill, the first person to be cremated at Woking Crematorium in March 1885, stated in her will:

I direct my executors after they have obtained a certificate (medical) of my death and before the coffin is closed to cause the arteries or large veins to be opened and I bequeath to my executors the sum of five pounds five shillings to be paid by them to Dr Langdon Down or any surgeon who may open the veins of my neck aforesaid. ${ }^{4}$

In this case, Dr. Down did not receive payment as Mrs. Pickersgill was subjected to an autopsy before cremation. Another example from 1909 also involved a physical assault on the corpse:

In the will of Dame Katherine Millicent Palmer, of Dorney House, Buckinghamshire, who died on January $10^{\text {th }}$, aged sixty-six years, widow of Sir Charles James Palmer, leaving estate of the gross value of $£ 2,876$, with net personalty $£ 2,598$, the following direction is set down concerning her remains: 'I have a great horror of being buried alive; therefore I wish my finger to be cut, and bequeath $£ 10$ to Dr Wilmot or any other doctor who is attending me at my death for such service'. ${ }^{5}$

The nineteenth-century fear that death-timings could be mistaken can be traced to a deficiency in the Registration of Births and Deaths Act 1836. 
This Act required a physician to supply a certificate confirming death, but it did not stipulate that a physical examination of the body must take place prior to its issue. On the medical certificate of the cause of death, the doctor could simply append "I am informed", leaving any person without medical qualifications or experience to state that life was extinct. As with all medical services at the time, the mandatory requirement for an examination would have involved the payment of a fee; for the poor, this would have represented a tax on death. Furthermore, tests for death would have been rudimentary and, perhaps, not necessarily conclusive. If a doctor was summoned, the diagnostic equipment in his bag would have comprised of little more than a stethoscope, a thermometer, an ophthalmoscope (for detecting decomposition in the retina), a hypodermic syringe (for injecting ammonia to detect inflammation), and a magnesium lamp (for examining circulation between the skin of the fingers). ${ }^{6}$

Among the poor, one fail-safe indicator that death had occurred was decomposition, especially the appearance of a green patch on the abdomen. ${ }^{7}$ Keeping the deceased at home in the interval between death and burial would have provided sufficient time for this change to become apparent. ${ }^{8}$ During this period, the undertaker would call to take a measurement and return to encoffin the body; a return visit may also have been necessary to seal the coffin if significant deterioration had taken place. It was not until the 1920s, that bodies were brought to the undertaker for more extensive treatment and transition to the chapel of rest, so an extended access to the body was important for assuaging fears of premature burial among the nineteenth-century poor. ${ }^{9}$ Long periods between death and burial were not uncommon. In his account of working as a gravedigger in the Suffolk village of Akenfield from the interwar years onwards, William Russ indicated that bodies would be kept at home for up to twelve days, not only because people "didn't care to part with it," but also because they "were afraid the corpse might still be alive." 10

\section{The Changing Context of Disposal}

Population expansion in the nineteenth century presented numerous social and economic challenges. As regards the disposal of the dead, the 1830s saw the introduction of death registration and the end of the Church of England's near-monopoly on burial provision by the establishment of proprietary cemetery companies. By the 1850s, Burial Board 
cemeteries funded by local ratepayers were transforming the landscape of burial in urban areas. With the increase in places approved for burial, and an increase in the means for disposing of the dead, the interval between death and burial was shortened. This allowed fears of premature burial to flourish, causing further changes in services for the disposal of bodies. The next section considers five of the main changes that occurred in the late nineteenth century.

The first development was cremation. In January 1874, the publication of Sir Henry Thompson's seminal paper "The Treatment of the Body after Death" led to the founding of the Cremation Society of England (CSE) and the building, five years later, of the first crematorium at Woking (however, because of issues concerning the legality of cremation, it was not until March 1885 when the cremator was used for the first time). ${ }^{11}$ At first, this alternative to burial was not popular; there were two further cremations in 1885, ten in 1886, and thirteen in 1887. By 1900, only 444 cremations took place at the four crematoria then in operation, representing only $0.07 \%$ of deaths in the UK.

The CSE were aware that cremation could be used to conceal crime so Thompson joined his fellow physicians in the Society (including the surgeon Sir Thomas Spencer Wells and Ernest Hart, the editor of the British Medical Journal) in devising the certification required to ensure the cause of death had been ascertained. The CSE was influenced by the French system in which a Medecin Verificateur was engaged by the state to confirm death; indeed, Sir Henry included an example of a form used in the French system in his 1899 book Modern Cremation: Its History and Practice. Based on this system, the Society required the completion of a series of certificates by three physicians: one to give the cause of the death; a second to confirm this information; and a third, appointed by the crematorium to be the "medical referee," who independently reviewed all the documentation. Initially, Thompson himself vetted all the documents in his capacity as the first Medical Referee at Woking. A slightly modified system of this death certification was adopted by all the other crematoria opening after Woking, and the usage of these documents became formalised in the Cremation Act 1902. Between 1885 and the commencement of the legislation in 1903 , nearly 3,300 cremations took place using this documentation.

The second key development was the building of mortuaries. From the 1870s onwards, the medical press published numerous accounts of the insanitary conditions in which bodies were retained at home, along 
with the continued prevarication by parishes, districts, the Metropolitan Board of Works and the Home Office over the provision of mortuaries. ${ }^{12}$ In 1875, the British Medical Journal surveyed facilities in London and found that out of the 20 districts that replied, just under half had no mortuary accommodation, whilst 13 had no post-mortem room. ${ }^{13}$ The few mortuaries that had been opened, such as at Clerkenwell, Marylebone, and Bow, were poorly appointed and this put off the people who needed them most. A report on the health of Marylebone published in 1875, suggested that the use of the parish mortuary for storing coffins had declined. The Lancet remarked: "The duty of educating the poor to overcome their prejudice against using mortuaries is as clear as is the duty of the urban sanitary authorities to provide them". ${ }^{14}$ This view was still prevalent in the 1920s when Bertram Puckle noted,

The thought that the bodies of friends and relations should be taken to a mortuary suggests to the average mind an indignity, a social degradation. The mortuary is regarded as especially provided by the State for the bodies of unfortunate outcasts picked up from the gutter, or dragged from the river, or at the best, as a place where the suicide or a person meeting with some dreadful accident is impounded till a jury can be called together for an inquest. We associate it mentally with the prison and the workhouse. ${ }^{15}$

The Public Health (London) Act 1891 finally made it mandatory for every sanitary authority in the capital to provide a mortuary. ${ }^{16}$ Mortuaries could take many different forms: in 1904, the Borough of Kensington constructed a "chapel of rest", as it was termed, in Avondale Park, Notting Hill. ${ }^{17}$ Despite being located in an area of dense housing, its use was only modest, as was reported over 20 years later:

We fear, however, that there is a still a tendency of the part of persons living in tenements of one, two or three rooms to retain in their tenements the bodies of deceased relatives awaiting burials, and that the accommodation afforded by the chapel was greatly overlooked. ${ }^{18}$

Despite being designated a "chapel of rest", this facility was on a similar footing to any other mortuary, being no more than a communal storage space provided by the local authority. It was, however, undertakers who addressed popular prejudice against mortuaries by opening private chapels of rest where the coffin could rest until the funeral. Furnished in an 
ecclesiastical manner and open to access without charge, such chapels can be found from around 1914, particularly in the urban areas. These early mortuaries and chapels of rest were, however, spaces to accommodate the dead; they were not akin to the "waiting mortuaries" provided in Paris and elsewhere in Europe, to which the dead were transferred until decomposition confirmed death.

The third point concerns change within the funeral industry. The two key functions of the nineteenth-century undertaker were the provision of the coffin, and the subsequent arranging of transportation to the place of disposal. Other goods and services were also supplied for those who could afford it, such as mourning wear (including hatbands and gloves). As already identified, the undertaker's contact with the dead body was no more than lifting it into a coffin, although occasionally embalmments took place for overseas transportation of the dead. In 1900, there was a turning point in the function of the undertaker when two embalming tutors toured Britain, leading sessions in the craft of arterial preservation of the dead, a technique already well-developed in the United States. ${ }^{19}$ Practitioners of this method formed an association, the British Embalmers' Society, with the support of fluid manufacturers, from whom it was hoped undertakers would make purchases. The Undertakers' Journal, which had been founded in 1885 and regularly published articles penned by the leading US practitioners, lent its support to embalmers. However, as with cremation, change was slow to come to the funeral industry. Very little embalming took place in the early part of the twentieth century, and when it did, treatment was at home and was costly. Nevertheless, embalming gave undertakers a professional credibility by their acquisition of anatomical and sanitary knowledge, the founding of a qualifying association and, in 1908, the publication of a code of ethics. This trend toward professionalisation was symbolised by the creation of the British Undertakers' Association, with the primary objective being state registration.

The fourth aspect of changing services in the late nineteenth century concerns legislation relating to aspects of disposal. Whilst burial grounds became increasingly regulated, doctors were still not required to examine the deceased before giving a death certificate. The CSE promoted the Disposal of the Dead (Regulations) Bill 1884, which was designed to regulate cremation and also introduce a physical examination of the deceased, but their initiative failed. Meanwhile, in 1893, the Departmental Committee on Death Certification drew attention to the 
absence of mandatory inspection of the body and noted that "in some instance a skilled observer would only be able to pronounce whether life was extinct". ${ }^{20}$ Again, few of its recommendations were implemented.

The fifth area was the reform of the funeral sector. Around the time that cremation was being promoted in the mid-1870s, the surgeon and etcher Sir Francis Seymour Haden defended the practice of burial against the cremationists. Haden argued that, if carried out correctly, using wicker or papier mâché "Earth to Earth" coffins interred in sandy, porous soil, would allow the body to deteriorate swiftly to its constituent elements. This would also allow others to reuse the grave. ${ }^{21}$ Another attack on emboldened undertakers came from the Church of England Funeral and Mourning Reform Association, founded in 1875 by the Reverend Frederick Lawrence. This group concerned itself with the "excessive cost and cynical manipulation of funerals by undertakers". ${ }^{22}$

Within the funeral industry, the Paddington-based funeral director and proprietor of The Undertakers' Journal, Halford Lupton Mills, also pursued a reform agenda. ${ }^{23} \mathrm{He}$ encouraged the use of the open-sided horse-drawn hearse, rather than an elaborate closed carriage, and dismissed the sale of unnecessary paraphernalia, including the use of mutes and the carrying of trays of feathers. The trend for advertising a scale of charges for funerals in newspapers and trade directories also suggests that some undertakers were keen to distance themselves from the unscrupulous behaviour of some colleagues. Whilst the overall purpose of these reforms was to reduce funerary expenditure through simplified disposal practices, they did not, however, address the issue of certification, nor did they provide reassurance to those concerned by the possibility of being buried alive. It was the latter that led to the founding of a pressure group specifically for this purpose.

\section{Premature Burial and the Undertakers}

In 1896, the London Association for the Prevention of Premature Burial (LAPPB) was established by William Tebb and a Gloucester-based general practitioner, Dr. Walter Hadwen. Tebb and Hadwen were stimulated by accounts of vivisepulchre in the popular press during 1895, and the following year Tebb wrote a book on the subject with Edward Vollum entitled Premature Burial and How It May Be Prevented. Both Tebb and Hadwen were on the fringes of medical orthodoxy because of their support for anti-vaccination, anti-vivisection, and vegetarian causes. Between 
1901 and 1914, the Association intervened in debates on funerary practices through its journal, the Burial Reformer (renamed Perils of Premature Burial in 1909).

Despite the generous coverage of LAPPB in The Undertakers' Journal, it mirrored the funeral sector as a whole in oscillating between expressions of ridicule and support for the movement. For instance, in 1898, the editor commented that "Premature burial, [was] an unwholesome and unnecessary subject in England", 24 whilst previously stating that "Tenders for the supply of premature burial stories are not invited at this office". ${ }^{25}$ In 1909, when the title of the Burial Reformer changed, the editor of The Undertakers' Journal suggested as alternatives The Medical Sinecurist (insinuating that physicians could earn a healthy income from certifying deaths) or The Burial Fiction Monthly. ${ }^{26}$ In its journal, the LAPPB published many accounts of people who were buried alive. ${ }^{27}$ Of these, only a case of catalepsy in 1905 contained any measure of credibility. This involved a young woman who was certified dead by a physician acting on information provided by the family. Luckily, she was discovered alive by an undertaker taking a measurement for her coffin. ${ }^{28}$ The response of The Undertakers' Journal was to publish letters requesting definite cases of premature burial. The LAPPB must have been very disappointed when Dr. Frederick Waldo, the South London Coroner, stated that he had come across no proven cases of premature burial. ${ }^{29}$

In the year following the founding of the LAPPB, the Secretary of State for the Home Office was asked about a Lancet report that stated that 15,000 people were buried annually without medical certificates. ${ }^{30}$ This figure was denied and it was further stated that no cases of premature burial had been brought to the attention of the Home Office. This did not persuade Sir Henry Thompson who pointed to a national problem:

Previous to cremation, let me say that it is sine qua non that a careful examination of the body by two medical practitioners (neither of whom is related to the deceased) must be made, and the cause of death clearly stated...In England and Wales an average of fifteen thousand are buried annually without a certificate of any sort, and the proportion is much larger in Scotland, amounting to about 50 per cent. ${ }^{31}$

The lack of mandatory death certification was an issue that energised undertakers, and those concerned about premature burial. In 1905, 
the British Undertakers' Association (BUA) was founded, and it joined the LAPPB in addressing the issue. However, for the undertakers, this campaign was part of their desire to offer more services and develop professional credibility; the LAPPB preferred to raise awareness of the deficiencies in the certification system through sensational reporting. Despite this, The Undertakers' Journal backed up some of the claims of the LAPPB in 1908, when it was stated that thirteen cases of premature burial were reported in the previous year. ${ }^{32}$

Despite this sensationalism, practical proposals did emerge. Inspired by examples in France and Germany, the LAPPB campaigned for the building of "waiting mortuaries" where the corpse could rest until signs of decomposition proved death had occurred. With grudging use of public mortuaries as they were, there was certainly no appetite for this initiative. The following year, the LAPPB suggested that the occupier of a household should be obliged to instruct a Medical Officer of Health to remove a body into their care prior to burial or cremation. ${ }^{33}$ Encouraged by a proposed bill in Massachusetts in 1903, they drafted legislation that floated the idea of a "death verifier" whose role would be to allow burial only after the body showed signs of decomposition. ${ }^{34}$

On the part of the undertakers, the funeral director James Broome argued that medical examiners [death certifiers] were too expensive and that people were not insured if they used their services. He proposed a solution: "Where uncertainty of death exists...call in a member of the British Embalmers' Society who is conversant with signs and tests". ${ }^{35}$ Broome recommended that all funeral directors carry out tests for death, while the founding father of the British Undertakers' Association and embalming pioneer, Henry Sherry, appropriately suggested that embalmers should be trained in resuscitation. ${ }^{36}$ In 1909, a "Death Registration and Burial Bill" was discussed at the BUA convention by Albert Cottridge, a London funeral director and advocate of embalming and the registration of funeral directors. Cottridge argued that each district should appoint a public certifier of deaths; that no death should be registered unless a medical certificate had been completed following examination of the deceased; that a physician completing a medical certificate should be paid $2 \mathrm{~s} 6 \mathrm{~d}\left(12 \frac{1}{2} \mathrm{p}\right)$; and that the person registering the death should receive a certificate from the registrar, then hand this to the cemetery for endorsement before being returned to the registrar. The registration of stillbirths was also to be included. ${ }^{37}$ 
Outside the funeral sector, weaknesses in the certification system were highlighted. In 1910 a John Bull article by the barrister and legal expert on burials, Alfred Fellows, raised the issue, while the following year the Coroners' Law and Death Certification (Amendment) Bill sought to introduce recommendations from the 1893 and 1908 Select committee on death certification and Coroner's legislation respectively. None of these efforts, however, yielded any major change and there appeared to be little in the way of parliamentary or medical support. In 1910, The Undertakers' Journal wearily noted that "The present law of death certification offers every opportunity for premature burial and every facility for concealment of crime". 38

The outbreak of World War I curtailed the enthusiasm of the LAPPB, but by 1919 it was still calling for a public certifier of deaths. One of its members, the Reverend Hugh Chapman, chaplain of the Savoy Chapel, suggested that if a Cabinet Minister were to be buried alive, public attention might be awakened to the issue. ${ }^{39}$ In 1922, a less sensational comment came from the Association's president, Sir George Greenwood MP, who declared that the present certification system was "a disgrace and a national danger". The following year, it was the turn, once again, of the undertakers to propose legislation, and the BUA's secretary, James Hurry, suggested that all undertakers enlist the support of their MPs to change the law. He proposed:

That it shall be compulsory for medical men to view the body after death before granting a certificate

That the cause of death shall be placed on the certificate by the Registrar

Registration of still-born children. ${ }^{40}$

This coincided with the undertakers also drafting legislation for state registration containing a clause that members must attend a course of study in sanitation (embalming) and care of the deceased. ${ }^{41}$

Further proposed bills to improve the certification system were discussed by the BUA in 1922, whilst the President of the British Medical Association, Professor David Drummond, advocated a compulsory post-mortem examination. This was a certain, but costly and controversial way of preventing premature burial. ${ }^{42}$ Some improvement came with the Births and Deaths Registration Act 1926, 
particularly in respect of stillbirths and certification before disposal, but there was no broad political support for the public certifier and still no requirement for a doctor to see the body after death, despite the insertion of a clause requiring this during the third reading of the bill. ${ }^{43}$

By the interwar years, the landscape of funerals and the work of the funeral director had changed. In 1927, a second association, the British Institute of Embalmers (BIE), was founded to provide formal training and a qualification. As the number of practitioners and availability of the treatment increased, the cost decreased and more funeral directors advocated embalming. Recognising the issue of premature burial, the BIE syllabus commenced with instructions on how to test for death before treatment. Whilst the comment of the American embalmer, O.K. Buckhout, that "embalming prevents the possibility of premature burial" was correct, the consequence of raising and injecting the carotid artery if the person was still alive would have been catastrophic. ${ }^{44}$ Testing for death by funeral directors and embalmers was logical as they had the experience of handling the dead on a routine basis. Cottridge included a chapter on the subject in his book Anatomy and Sanitation, published in 1925, while Medical Officers of Health addressing the annual BUA convention frequently referred to the need for the tests to be carried out. ${ }^{45}$ The merits of the different tests often became a discussion point within the pages of the trade journals. ${ }^{46}$

In this changed landscape, testing for death was a service that gave people confidence that funeral directors and embalmers could treat the body appropriately. This confidence was especially important in the 1930s when it was claimed that $60 \%$ of deaths were certified without the doctor having seen the body. ${ }^{47}$ Despite some support from general practitioners for their practice, funeral directors and embalmers did not receive universal backing from the British medical community. Not only did training for embalming lack external accreditation, but embalming tutors did not typically have medical experience. But perhaps the key reason for the reluctance of the medical community to approve of funeral directors having a role, similar to the French Medecin Verificateur was that this would have usurped the doctor's presence at the dying person's bedside.

Despite the lack of formal validation in their quest, undertakers continued to be interested in the tests for death. In 1927, a dye was demonstrated at the BUA Convention that could be injected into the body 
to determine whether life was extinct. The effects of the "infallible and harmless" Obiturin were discussed in a report of the proceedings:

Previous to the lecture Mr AG Hurry had submitted himself to an experimental demonstration to the effect of Obiturin on the living human body. The injection was made in Mr Hurry's forearm while a like experiment was performed upon the lecturer by Ald [Alderman] Kenyon. The result was awaited with great interest and those present had the satisfaction of observing an interesting reaction, Mr Hurry going round the room in order that all present might examine at close quarters the green discolouration which proved that he was very much alive. ${ }^{48}$

By the late 1930s, physicians were required to examine bodies and sign death certificates in the increasing number of state institutions in Britain. This trend continued particularly after the founding of the National Health Service in the late 1940s. Despite a continued low preference for cremation (in 1927 only $0.59 \%$ of deaths were followed by cremation), people could now be confident that premature burial was unlikely given the requirement for two physicians to carry out a careful external examination of the body. ${ }^{49}$ However, while there is evidence to show that in urban areas the preference for cremation shifted dramatically when local facilities were provided, it would be another 40 years before the trend spread outside the cities. It was only in 1965 that cremations outnumbered burials for the first time. ${ }^{50}$

The LAPPB, meanwhile, limped along into the 1930s. ${ }^{51}$ Hadwen died in 1932, and three years later the Association become affiliated with the National Council for the Disposition of the Dead (NCDD), an organisation with an agenda to promote cremation along with the registration of funeral directors. However, the minutes indicate that by the second meeting, the LAPPB was not listed as a participant, and the NCDD failed in any case due to lack of support. ${ }^{52}$ The quest for a public certifier and the construction of "waiting" mortuaries was never realised, particularly as by the 1940s the vast majority of funeral directors had opened chapels of rest in their private premises, where more embalming was taking place. Remarkably, the law was never changed to require a doctor to examine a person after death, unless cremation was called for.

While concerns about premature burial in the nineteenth century had their basis in a deficiency in legislation and medical practice, for 
most people, declaration of the fact of death would often have come from informal care-givers who nursed the dying. Their ability to recognise the boundary between life and death was solely dependent on past experience. Given the landscape of death and burial in Britain today, with professional funeral directors managing the treatment and disposal of most corpses, the informal knowledge about bodies and decomposition that people, especially the poor, possessed is worth reflecting on. Yet, the number of cases where the signs of death were misinterpreted needs to be viewed in perspective. While the LAPPB highlighted only a few factually proven incidents, the scale of the issue was unknown. It was one thing if a person was found to be living before burial, but quite another if a person was found to have lived after interment had taken place. Theoretically speaking, without mass exhumations, it is impossible to know how many bodies show signs of life after interment. Undertakers seized on this macabre situation as an opportunity to exercise power over the body by becoming the self-appointed person to carry out the tests for death. Although it was not easily gained, this power gave them a new status as quasi-medical practitioners and helped shed the Dickensian image of disreputability inherited from their nineteenthcentury forebears.

Today, the possibility of premature burial in Britain has been diminished by several factors: Due to shifts in the culture of death and dying, a large proportion of deaths now take place in institutions where physicians with a range of diagnostic equipment are on hand to confirm death. Furthermore, the majority of deaths are now followed by cremation, and this requires two doctors to examine the deceased. In addition, the interval of 5-14 days between a person's death and funeral, along with the widespread adoption of embalming, has reduced the possibility of a premature burial. Nevertheless, knowledge of the tests for death still remains part of the Diploma in Funeral Directing examination in Britain, while the National Association of Funeral Directors' Manual of Funeral Directing states: "Every funeral director should be able to satisfy himself, and on occasion the family, that death has actually taken place". ${ }^{53}$ However, as legislation still does not require a doctor to examine the deceased before completing the Medical Certificate of the Cause of Death, the issue continues to engage the minds of funeral directors, if not the general public. 


\section{Notes}

1. George K. Behlmer, "Grave Doubts: Victorian Medicine, Moral Panic, and the Signs of Death", Journal of British Studies, 42:2 (2003), p. 207. See also Jan Bondeson, Buried Alive: The Terrifying History of Our Most Primal Fear (New York, 2001); Joanna Bourke, Fear: A Cultural History (London, 2005).

2. Ralph H. Major ed., "Devices to Prevent Premature Burial", Journal of the History of Medicine and Allied Sciences, 3:1 (1948), pp. 161-171.

3. "The Life-Saving Coffin", The Undertakers' Journal [hereafter TUJ], 36:2 (1912), p. 38. See also "Coffin for the Living”, TUJ, 20:5 (1905), p. 116.

4. Will dated 20 December 1882, copy in author's collection.

5. "Horror of Premature Burial", TUJ, 24:8 (1909), p. 52. See also “Making Sure of Death", TUJ, 24:5 (1909), p. 105; "Fear of Premature Burial”, TUJ, $42: 9$ (1927), p. 318.

6. Behlmer, "Grave Doubts", p. 217.

7. "Death Certificates: Urgent Need of Reform of the Law", TUJ, 26:11 (1911), p. 296. See also "Fear of Premature Burial", British Undertakers' Association Monthly [hereafter BUAM], 10:10 (1931), p. 232.

8. See Julie-Marie Strange, Death, Grief and Poverty in Britain, 1870-1914 (Cambridge, 2005).

9. See Brian Parsons, The Undertaker at Work: 1900-1950 (London, 2014).

10. Ronald Blythe, Akenfield: Portrait of an English Village (New York, 1969), p. 313.

11. See Brian Parsons, Committed to the Cleansing Flame: The Development of Cremation in Nineteenth-Century England (Reading, 2005).

12. See Pam Fisher, "Houses for the Dead: The Provision of Mortuaries in London, 1866-1889", The London Journal, 34:1 (2009), pp. 1-15.

13. See "Mortuaries for the Metropolis," The British Medical Journal (1875), pp. 802-803.

14. "Prejudice against Mortuaries", The Lancet (1875), p. 331.

15. Bertram S. Puckle, Funeral Customs: Their Origin and Development (London, 1926), p. 28.

16. Albert Chambers Freeman, The Planning of Poor Law Buildings and Mortuaries (London, 1906); “A Public Mortuary and Post-Mortem Room", The Lancet (1870), p. 318.

17. Borough of Kensington Council Minutes, 29 March 1904, p. 236; 5 July 1904, p. 346. The Royal Borough of Kensington \& Chelsea, Local Studies Library.

18. Ibid., 18 January 1927, p. 111.

19. See Parsons, The Undertaker. 
20. Reports from the Select Committee on Death Certification (London, 1893), p. xiii.

21. Parsons, Committed to the Cleansing Flame, pp. 204-220.

22. Ibid., p. 212.

23. See Brian Parsons, "Halford Mills: Funeral Reformer and Pioneer of Embalming”, Funeral Service Journal (2005), pp. 64-72.

24. "Notes", TUJ, 13:6 (1898), p. 83.

25. "Notes", TUJ, 11:6 (1896), p. 82. See also "Editorial: How to Prevent Premature Burial", TUJ, 18:7 (1903), pp. 165-166.

26. "Notes", TUJ, 24:3 (1909), p. 50.

27. "Burial Alive", TUJ, 13:8 (1898), p. 124; "Notes", TUJ, 13:11 (1898), p. 159; "Reported Cases of Premature Burial", TUJ, 18:5 (1903), p. 110; "Recent Live Burial Cases", TUJ, 19:5 (1904), p. 97.

28. See "Notes", TUJ, 20:2 (1905), p. 26; "The Accrington Catalepsy Case", TUJ, 20:2 (1905), p. xi.

29. "Letter to the Editor. Burial Alive", TUJ, 16:8 (1901), pp. 188-189; "Notes", TUJ, 19:2 (1904), p. 36.

30. The Lancet (1897), pp. 1155-1156.

31. "Cremation", TUJ, 12:7 (1897), p. 95.

32. "Editorial. Premature Burial", TUJ, 23:2 (1908), pp. 35-36; "Premature Burial. Thirteen Cases During the Past Year", TUJ, 23:2 (1908), p. 36; "Notes", TUJ, 23:3 (1908), pp. 53-54.

33. "A Bill to Prevent Alive Burial", TUJ, 16:6 (1901), pp. 136-137.

34. "Notes", TUJ, 18:12 (1903), p. 260; "Notes", TUJ, 19:12 (1904), p. 245; "Notes", TUJ, 20:1 (1905), p. 2.

35. "Letter to the Editor. The Prevention of Premature Burial", TUJ, 20:1 (1905), p. 16.

36. H. Sherry, "The Sanitary Advantages of Modern Embalming", TUJ, 20:8 (1905), pp. 188-189.

37. A.J.E. Cottridge, "The Death Registration and Coroner's Bill", TUJ, 24:7 (1909), pp. 171-172.

38. A. Fellows, "Death Certificates: The Weaknesses of the Present Law", TUJ, 25:11 (1910), p. 266; "Coroners' Law and Death Certification (Amendment) Bill”, TUJ, 25:12 (1910), pp. 292-294.

39. "Premature Burial", BUAM, 1:11 (1922), p. 251.

40. "Registration of Deaths", BUAM, 2:9 (1923), p. 248.

41. "Registration", BUAM, 1:11 (1922), pp. 250-251.

42. "Post-Mortem Examinations for All", BUAM, 1:4 (1922), p. 74.

43. "Births and Deaths Registration Bill", TUJ, 41:3 (1926), p. 73; "Notes", TUJ, 41:4 (1926), p. 105. See also "Births and Deaths Registration Bill", Hansard, 26 February 1926, Cols 977-998; "Births and Deaths 
Registration Bill' Hansard, 18 June 1926, Cols 2684-2692; S.A. Smith, “Cremation and Crime", TUJ, 45:9 (1930), pp. 295-298.

44. "The Art and Use of Embalming”, TUJ, 15:7 (1900), p. 78.

45. A.J.E. Cottridge, Anatomy and Sanitation (London, 1925), pp. 103-104; "Proposed Syllabus of Instruction in Sanitation", BUAM, 2:1 (1922), p. 2.

46. E.P. Vollum, “Last Tests for Death”, TUJ, 19:4 (1904), pp. 80-81. See also F.A. Sharpe, "Modes of Death”, BUAM, 1:12 (1922), p. 276; A.J.E. Cottridge, "Signs of Death", BUAM, 11:4 (1931), pp. 82-83; G.C.F. Rose, “Tests for Cause of Death", BUAM, 11:8 (1932), p. 183.

47. "Editorial: Imagination and Progress", TUJ, 45:2 (1930), p. 56.

48. "Lecture on Obiturin", BUAM, 7:2 (1927), pp. 44-46.

49. See also "Premature Burial", The Times, 31 March 1927; "The Federation of Cremation Authorities in Great Britain", TUJ, $42: 7$ (1927), pp. 245-246.

50. See Peter C. Jupp, From Dust to Ashes: Cremation and the British Way of Death (Basingstoke, 2005).

51. "Personal", The Times, 10 July 1930; "News in Advertisements!", The Times, 24 June 1931.

52. Jupp, From Dust to Ashes, pp. 114-115; "Prevention of Premature Burial!", The Times, 5 February 1936; "National Council for the Disposition of the Dead", BUAM, 14:12 (1935), p. 246.

53. Manual of Funeral Directing (London, 1976), p. 45.

\section{Author Biography}

Brian Parsons has worked in funeral service in London since 1982. His Ph.D. focused on the impact of change, during the twentieth century, on the funeral industry. He is the author of The London Way of Death, Committed to the Cleansing Flame: The Development of Cremation in Nineteenth Century England and The Undertaker at Work: 1900-1950. 
Open Access This chapter is licensed under the terms of the Creative Commons Attribution 4.0 International License (http://creativecommons.org/licenses/ by $/ 4.0 /$ ), which permits use, sharing, adaptation, distribution and reproduction in any medium or format, as long as you give appropriate credit to the original author(s) and the source, provide a link to the Creative Commons license and indicate if changes were made.

The images or other third party material in this chapter are included in the chapter's Creative Commons license, unless indicated otherwise in a credit line to the material. If material is not included in the chapter's Creative Commons license and your intended use is not permitted by statutory regulation or exceeds the permitted use, you will need to obtain permission directly from the copyright holder.

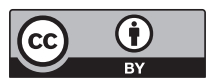

